\title{
Efficient Antimicrobial Activities of Microwave-assisted Synthesis of Benzisoxazole Derivatives
}

\author{
J. UMAMAHESWARI ${ }^{1}$, P. RAMANATHAN ${ }^{2}$ and V. NADARAJ ${ }^{3 *}$ \\ ${ }^{1}$ Department of Chemistry, RVS Technical Campus, Coimbatore-641402, India. \\ ${ }^{2}$ Department of Chemistry, Thanthai Hans Roever College (Autonomous), \\ Perambalur-621220, Tamilnadu, India. \\ ${ }^{3}$ Department of Chemistry, Tamilnadu College of Engineering, Karumathampatti, \\ Coimbatore-641659, India \\ ${ }^{*}$ Corresponding author E-mail: ramanathanp2010@gmail.com \\ http://dx.doi.org/10.13005/ojc/360307
}

(Received: February 07, 2020; Accepted: May 05, 2020)

\begin{abstract}
The present study deals with the synthesis of benzisoxazole derivatives beginning from 5,5-dimethyl cyclohexane-1,3-dione by making use of a microwave reactor. The microwave reactions are effortless, well-organized, clean, swift and financially viable for the synthesis of a huge amount of organic molecules, have offered the drive for many chemists to change from conventional heating methods to microwave-assisted chemistry. In latest years, microwave synthesized organic reaction has appeared as a new device in organic synthesis. The synthesized compounds were for the studie by using IR, NMR, mass spectra and antimicrobial studies also carried out.
\end{abstract}

Keywords: Benzisoxazole, IR, NMR, Antimicrobial.

\section{INTRODUCTION}

Microwave assisted synthesis is an eco-friendly and well-organized synthesis of organic compounds in contrast to the conventional process. In this system, reaction takes place more swiftly, securely and with advanced chemical yields and thus, this method becomes greater to the conventional mode.

Benzisoxazole exhibits a remarkable prospective as antimicrobial, anticancer, anti-inflammatory actions. In medicinal chemistry as it relates to the broad and general outline of the different benzisoxazole analogs, their application as beginning building blocks of diverse architectures on scales adequate to drive human drug experiments. ${ }^{1-5}$ Heterocyclic molecules such as benzisoxazole derivatives, particularly 3-(piperidin4-yl)-1,2-benzisoxazole have been extensively used as antipsychotic drugs. ${ }^{6}$ Atypical antipsychotic drugs which are derived from benzisoxazole. ${ }^{7}$ Benzisoxazole derivatives are oxygen, nitrogen holding heterocycles with broad variety of synthetic and pharmaceutical applications, and are renowned for biological activities. The high therapeutic

This is an Open Access article licensed under a Creative Commons license: Attribution 4.0 International (CC- BY). Published by Oriental Scientific Publishing Company @ 2018

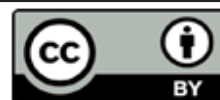


properties of these heterocycles have persuaded the medicinal chemist to synthesize a huge quantity of chemotherapeutic agents. ${ }^{8}$

Isoxazole is a vital heterocyclic core, which is broadly used as many pharmacological properties. $^{9-12}$ We herein detail the synthesis of benzisoxazole derivatives from dimedone with the use of microwave irradiation.

\section{EXPERIMENTAL}

\section{MATERIALS AND METHOD}

Dimedone, benzaldehyde and hydroxylamine hydrochloride were provided by Sigma-Aldrich (St.Louis, USA). IR spectra were documented in SHIMADZU FT-IR 8400 S spectrometer by employing $\mathrm{KBr}$ pellets. ${ }^{1} \mathrm{H}$ NMR $(500 \mathrm{MHz})$ and ${ }^{13} \mathrm{C}$ NMR $(400 \mathrm{MHz})$ spectra recorded on Brucker spectrometer using $\mathrm{CDCl}_{3}$ solvent. Microwave (Godrej GMS 17M 07 WHGX). Melting point was recorded in Royal Scientific RSW 138 B.

\section{Synthesis of benzisoxazole derivatives}

5,5-dimethylcyclohexane-1,3-dione $(0.001$ $\mathrm{mm})$ react with hydroxylamine hydrochloride $(0.001$ $\mathrm{mm}$ ) and benzaldehyde $(0.1 \mathrm{~mL})$ under microwave irradiation at a suitable time (Table 1). The development of the reaction was monitored on TLC (Scheme 1). Following the completion of reaction, the reaction combination was quenched in distilled water and the precipitate was formed. It were filtered and dried.

Table 1: Melting point, yield and time taken for microwave irradiation of the benzisoxazole derivatives 1-4

\begin{tabular}{cccc}
\hline Compounds & m.p $\left({ }^{\circ} \mathrm{C}\right)$ & Yield $(\%)$ & Time $(\mathrm{min})$ \\
\hline 1 & 158 & 86 & 7 \\
2 & 162 & 75 & 9 \\
3 & 152 & 78 & 8 \\
4 & 144 & 80 & 7 \\
\hline
\end{tabular}

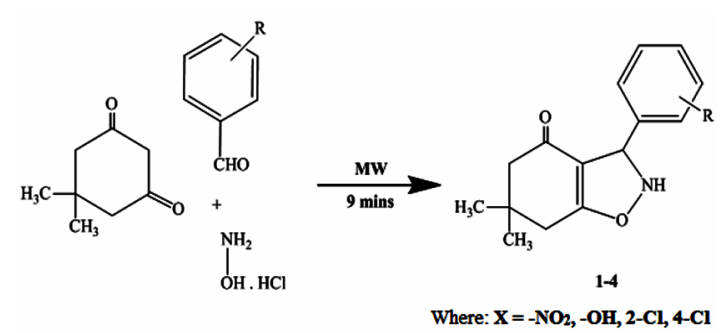

Scheme 1. Synthetic route of benzisoxazole derivatives

\section{Antibacterial studies}

Antibacterial studies, Gram-positive and Gram-negative strains have been used for the study B. subtilis, E. coli, P. aeruginosa, S. aureus, S. pyogenes. Antifungal studies, used following fungal strains, A. flavus, A. niger, P. chryogenum, T. veride, F. oxysporum.

\section{RESULTS AND DISCUSSION}

\section{IR and NMR spectrum of benzisoxazole derivatives (1-4)}

Synthesis of benzisoxazole derivatives (1-4) by utilizing microwave irradiation for suitable time ( $9 \mathrm{~min}$ ) afforded remarkable yields with absolute transformation of reactants. The foundation of newly synthesized (1-4) was launched by IR and NMR spectroscopy.

\section{3-(2-chlorophenyl)-6,6-dimethyl-2,3,6,7-} tetrahydrobenzo[d] isoxazol-4(5H)-one (1)

FT-IR spectrum the carbonyl $(\mathrm{C}=\mathrm{O})$ and $\mathrm{N}-\mathrm{H}$ stretching frequency were scrutinized in the area of 1688 and $3666-3750 \mathrm{~cm}^{-1}$. The C-N and aromatic $\mathrm{C}=\mathrm{C}$ stretching frequency were examined at 2360 and $1548 \mathrm{~cm}^{-1}$.

Molecular formula is $\mathrm{C}_{15} \mathrm{H}_{16} \mathrm{CINO}_{2}:{ }^{1} \mathrm{H}$ NMR $\left(500 \mathrm{MHz}, \mathrm{CDCl}_{3}\right): \delta 1.16(\mathrm{~s}, 6 \mathrm{H}), 2.33$ $(\mathrm{s}, 1 \mathrm{H}), 2.34(\mathrm{~s}, 2 \mathrm{H}), 2.44(\mathrm{~s}, 2 \mathrm{H}), 5.50(\mathrm{~s}, 1 \mathrm{H}), 7.02$ $(d, J=3.0 \mathrm{~Hz}, 3 \mathrm{H}), 7.24(\mathrm{t}, 2 \mathrm{H}), 7.45(d, J=8.0 \mathrm{~Hz}$, 1H). ${ }^{13} \mathrm{C}$ NMR $\left(400 \mathrm{MHz}, \mathrm{CDCl}_{3}\right): \delta 27.67,31.76$, $41.62,51.16,59.14,104.47,126.99,128.05,128.59$, $129.35,142.79,187.47,198.93$. Theoritical value of MS: m/z. $277.75\left[\mathrm{M}^{+}\right]$.

\section{3-(4-chlorophenyl)-6,6-dimethyl-2,3,6,7-} tetrahydrobenzo[d] isoxazol- $4(5 \mathrm{H})$-one (2)

FT-IR spectrum the carbonyl $(\mathrm{C}=\mathrm{O})$ and $\mathrm{N}-\mathrm{H}$ stretching frequency were surveyed in the region of 1688 and $3666-3750 \mathrm{~cm}^{-1}$. The $\mathrm{C}-\mathrm{N}$ and aromatic $\mathrm{C}=\mathrm{C}$ stretching frequency were examined at 2360 and $1548 \mathrm{~cm}^{-1}$.

Molecular formula is $\mathrm{C}_{15} \mathrm{H}_{16} \mathrm{CINO}_{2}:{ }^{1} \mathrm{H}$ NMR $\left(500 \mathrm{MHz}, \mathrm{CDCl}_{3}\right): \delta 1.16(\mathrm{~s}, 6 \mathrm{H}), 2.33(\mathrm{~s}$, $1 \mathrm{H}), 2.40(\mathrm{~s}, 2 \mathrm{H}), 2.44(\mathrm{~s}, 2 \mathrm{H}), 5.10(\mathrm{~s}, 1 \mathrm{H}), 7.01(\mathrm{~d}$, $J=8.0 \mathrm{~Hz}, 1 \mathrm{H}), 7.25(d, J=12.0 \mathrm{~Hz}, 1 \mathrm{H}), 7.37(d$, $J=7.5 \mathrm{~Hz}, 1 \mathrm{H}), 7.45(d, J=8.0 \mathrm{~Hz}, 1 \mathrm{H}) .{ }^{13} \mathrm{C}$ NMR $\left(400 \mathrm{MHz}, \mathrm{CDCl}_{3}\right): \delta 27.67,31.76,41.65,51.14,62.47$, 104.45, 126.99, 128.59, 133.96, 141.56, 187.40, 198.91. Theoritical value of MS: $\mathrm{m} / \mathrm{z} .277 .75\left[\mathrm{M}^{+}\right]$. 
3-(4-hydroxyphenyl)-6,6-dimethyl-2,3,6,7tetrahydrobenzo[d] isoxazol-4(5H)-one (3)

FT-IR spectrum the hydroxyl $(-\mathrm{OH})$, carbonyl $(\mathrm{C}=\mathrm{O})$ and $\mathrm{N}-\mathrm{H}$ stretching frequency were examined in the area of 3852, 1688 and 3666$3750 \mathrm{~cm}^{-1}$. The $\mathrm{C}-\mathrm{N}$ and aromatic $\mathrm{C}=\mathrm{C}$ stretching frequency were detected at 2360 and $1548 \mathrm{~cm}^{-1}$.

Molecular formula is $\mathrm{C}_{15} \mathrm{H}_{17} \mathrm{NO}_{3}:{ }^{1} \mathrm{H}$ NMR $\left(500 \mathrm{MHz}, \mathrm{CDCl}_{3}\right): \delta 1.14(\mathrm{~s}, 3 \mathrm{H}), 1.29(\mathrm{~s}, 3 \mathrm{H}), 2.25$ (s, 1H), $2.37(\mathrm{~s}, 2 \mathrm{H}), 2.49(\mathrm{~s}, 2 \mathrm{H}), 5.56(\mathrm{~s}, 1 \mathrm{H}), 7.02$ $(d, J=8.0 \mathrm{~Hz}, 1 \mathrm{H}), 7.24(d, J=12.0 \mathrm{~Hz}, 1 \mathrm{H}), 7.37$ $(d, J=7.5 \mathrm{~Hz}, 1 \mathrm{H}), 7.45(d, J=7.9 \mathrm{~Hz}, 1 \mathrm{H}), 11.88$ (s, $1 \mathrm{H}) \cdot{ }^{13} \mathrm{C} \mathrm{NMR}\left(400 \mathrm{MHz}, \mathrm{CDCl}_{3}\right): \delta 27.66,31.76$, $41.65,51.14,61.47,104.65,115.17,126.99,135.96$, $139.55,156.59,187.40,198.91$. Theoritical value of MS: m/z. $259.30\left[\mathrm{M}^{+}\right]$.

\section{6,6-dimethyl-3-(3-nitrophenyl)-2,3,6,7-} tetrahydrobenzo[d] isoxazol-4(5H)-one (4)

FT-IR spectrum the carbonyl $(\mathrm{C}=\mathrm{O})$ and $\mathrm{N}-\mathrm{H}$ stretching frequency were detected in the area of 1688 and $3666-3750 \mathrm{~cm}^{-1}$. The C-N and aromatic $\mathrm{C}=\mathrm{C}$ stretching frequency were detected at 2360 and $1548 \mathrm{~cm}^{-1}$.

Molecular formula is $\mathrm{C}_{15} \mathrm{H}_{16} \mathrm{~N}_{2} \mathrm{O}_{4}:{ }^{1} \mathrm{H}$ NMR $\left(500 \mathrm{MHz}, \mathrm{CDCl}_{3}\right): \delta 1.15(\mathrm{~s}, 3 \mathrm{H}), 1.27(\mathrm{~s}, 3 \mathrm{H}), 2.25$ (s, 1H), $2.37(\mathrm{~s}, 2 \mathrm{H}), 2.49(\mathrm{~s}, 2 \mathrm{H}), 5.56(\mathrm{~s}, 1 \mathrm{H}), 7.56$ (t, $1 \mathrm{H}), 7.89(d, J=8.0 \mathrm{~Hz}, 1 \mathrm{H}), 7.72(d, J=7.9 \mathrm{~Hz}$, $1 \mathrm{H}), 8.43(\mathrm{~s}, 1 \mathrm{H}) \cdot{ }^{13} \mathrm{C}$ NMR $\left(400 \mathrm{MHz}, \mathrm{CDCl}_{3}\right): \delta$ 27.66, 31.76, 41.65, 51.14, 61.47, 119.32, 121.68, 129.84, 135.96, 147.12, 187.59, 198.91. Theoritical value of MS: $\mathrm{m} / \mathrm{z}$. $288.30\left[\mathrm{M}^{+}\right]$.

\section{Antimicrobial activities}

The preliminary antimicrobial activities of the moieties 1-4 are scrutinized using disc diffusion method. The bacterial strains viz., B. subtilis, E. coli, P. aeruginosa, S. aureus, S. pyogenes are used in this study. Dimethylsulphoxide is used as a control. Streptomycin and Amphotericin B are used as an indication for bacterial and fungal studies correspondingly.

The antibacterial screening studies indicated that the compound having 1,2, 4 showed outstanding antibacterial against B. subtilis, E. coli, $S$. pyogenes, but no active against $P$. aeruginosa and $S$. aureus. The compound 1 is more active against $P$. aeruginosa and S. pyogenes (Fig. 1). The results are given in Table 2. The antifungal activity screening studies confirmed that the 1, 2, 4 chloro substituted compound showed outstanding activity against A.flavus, P. chryogenum, F. oxysporum and less active against $A$. niger, T. veride (Fig. 2). The result is given in Table 3 .

Table 2: Antibacterial activity of compounds 1 to 4

\begin{tabular}{cccccc}
\hline S. No. & Bacteria & \multicolumn{5}{c}{ Zone of inhibition mm in diameter } \\
& & 1 & 2 & 3 & 4 \\
\hline 1 & B. subtilis & 25 & 20 & 20 & 31 \\
2 & E. coli & 18 & 8 & - & 22 \\
3 & P. aeruginosa & 26 & - & - & - \\
4 & S. aureus & 18 & 8 & - & - \\
5 & S. pyogenes & 17 & 12 & - & 19 \\
\hline
\end{tabular}

*Streptomycin

Table 3: Antifungal activity of compounds 1 to 4

\begin{tabular}{|c|c|c|c|c|c|}
\hline \multirow[t]{2}{*}{ S. No. } & \multirow[t]{2}{*}{ Fungi } & \multicolumn{4}{|c|}{$\begin{array}{l}\text { Zone of inhibition } \mathrm{mm} \\
\text { in diameter }\end{array}$} \\
\hline & & 1 & 2 & 3 & 4 \\
\hline 1 & Aspergillus flavus & 14 & 24 & - & 26 \\
\hline 2 & Aspergillus niger & 19 & 18 & - & 11 \\
\hline 3 & Penicillim chryogenum & 12 & 23 & - & 28 \\
\hline 4 & Trichoderma veride & 20 & 17 & - & 8 \\
\hline 5 & Fusarium oxysporum & 12 & 22 & - & 27 \\
\hline
\end{tabular}

${ }^{*}$ Amphotericin-B
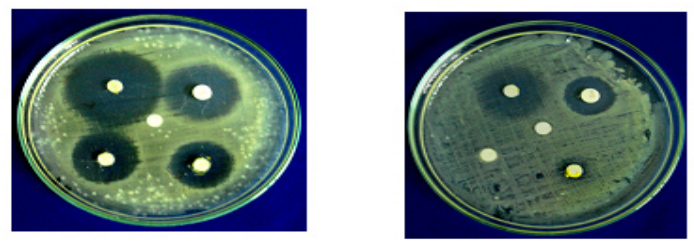

Bacillus subtilis

Escherichia coli
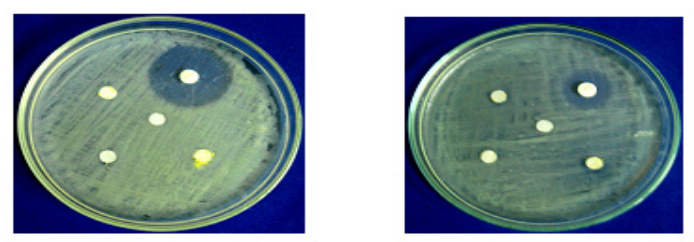

Pseud omonas aeruginosa Staphylococcus aureus

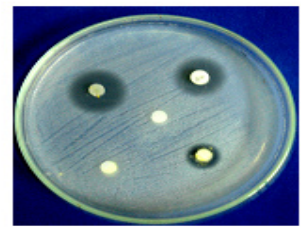

Strep tococcus pyogenes

Fig. 1. Zone of inhibition of moieties 1-4 against B. subtilis, E. coli, P. aeruginosa, S. aureus and S. pyogenes 

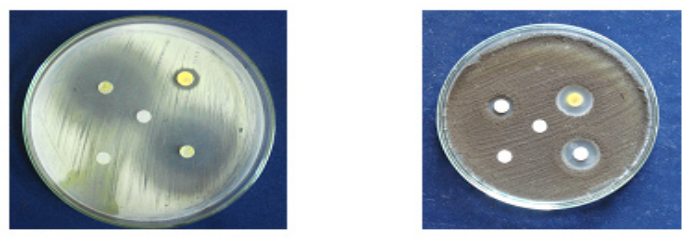

Aspergillus flav us

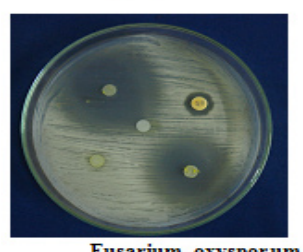

Fusarium oxysporum

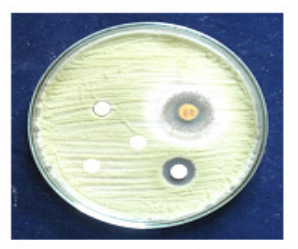

Trigoderma veride

Fig. 2. Zone of inhibition of moieties 1-4 against A. flavus, A. niger, F. oxysporum, P. chryogenum, T. veride

\section{CONCLUSION}

The depicted synthetic protocol permits for the preparation of a series of benzisoxazole derivatives as new arrangement which can be latently useful in various pharmacological applications. Chief benefits of these original techniques are equipped with effortlessness, high yield in a very tiny reaction time, eco-friendly conditions, very cheap, effortlessly available reagent and simple technique employed.

\section{ACKNOWLEDGMENT}

Special thanks to the V.N. the Director of Collegiate Education, Govt. of Tamilnadu, India,. Author is thanksful to Research Centre, IISc, Bangalore, for providing NMR facility. Thanks to Dr. P. Ramanathan, Assistant Professor, for helping me to complete the bioactivity tests.

\section{Conflict of interest}

No conflict of interest

\section{REFERENCES}

1. Rakesh, K.P.;Shantharam, C.S.; Sridhara, M.B.; Manukumar, H.M.; Qin, H.; Benzisoxazole: a privileged scaffold for medicinal chemistry, Med. Chem. Comm., 2017, 8(11), 2023.

2. Shin, K.D.; Lee, M.Y.; Shin, D.S.; Lee, S.; Son, K.H.; Koh, S.; Paik, Y.K.; Kwon, B.M.; Han, D.C.; Blocking Tumor Cell Migration and Invasion with Biphenyl Isoxazole Derivative KRIBB3, a Synthetic Molecule That Inhibits Hsp27 Phosphorylation, J. Biol. Chem., 2005, 280, 41439.

3. Demers, J.; Hageman, W.; Johnson, S.; Klaubert, D.; Look, R.; Moore, J.; Selective inhibitors of protein kinase $C$ in a model of graft-vs-host disease, J. Bioorg. Med. Chem. Lett., 1994, 4, 2451.

4. Simoni, D.; Roberti, M.; Paolo, I.F.; Rondanin, R.; Baruchello, R.; Malagutti, C.; Mazzali, A.; Rossi, M.; Grimaudo, S.; Capone, F.; Dusonchet, L.; Meli, M.; Raimondi, M.V.; Landino, M.; D'Alessandro, N.; Tolomeo, M.; Arindam, D.; Lu, S.; Benbrook, D.M.;
Heterocycle-Containing Retinoids. Discovery of a Novel Isoxazole Arotinoid Possessing Potent Apoptotic Activity in Multidrug and Drug-Induced Apoptosis-Resistant Cells,

J. Med. Chem., 2001, 44, 2308.

5. Rowley, M.; Broughton, H.B.; Collins, I.; Baker, R.; Emms, F.; Marwood, R.; Patel, S.; Patel, S.; Ragan, C.I.; Freedman, S.B.; Leeson, P.D.; 5-(4-Chlorophenyl)-4-methyl3-(1-(2- phenylethyl)piperidin-4-yl)isoxazole: A Potent, Selective Antagonist at Human Cloned Dopamine D4 Receptors, J. Med. Chem., 1996, 39, 1943.

6. Wittenberger, S.J.; An Efficient Synthesis of the Cholinergic Channel Activator ABT-418, J. Org. Chem., 1996, 61, 356.

7. Sharath chandra, S.P.; Sharada, A.C.; Benzisoxazole derivatives as Atypical Antipsychotic drugs: A Review, Int. J. Pharma Sci. Res., 2014, 5(12), 1006.

8. Shastri, R.A.; Review on Synthesis of 3-Substituted 1,2-Benzisoxazole Derivatives, Chem. Sci. Trans., 2016, 5(1), 8. 
9. Dannhardt, G.; Dominiak, P.; Laufer, S.; Hypertensive effects and structure-activity relationship of 5-omega-aminoalkyl isoxazoles, Arznei-Forschung., 1993, 43, 441.

10. Tatee, T.; Narita, K.; Kurashige, S.; Ito, S.; Miyazaki, H.; Yamanaka, H.; Mizugaki, M.; Sakamoto, T.; Fukuda, H.; Isoxazole Derivatives as Centrally Acting Muscle Relaxants. III. Synthesis and Activity of Conformationally Restricted Analogs, Chem. Pharm. Bull., 1987, 35, 3676.
11. Taylor, E.C.; Patel, H.; Kumar, H.; Synthesis of pyrazolo 3,4-dpyrimidine analogues of the potent agent N-4-2-2-amino-4 3H-oxo-7H-pyrrolo 2,3dpyrimidin-5-yl ethylbenzoyl-L-glutamic acid (LY231514), Tetrahedron., 1992, 48, 8089.

12. Abdel-Rahman, A.A.H.; Abdel-Megied, A.E.S.; Hawata, M.A.M.; Kasem, E.R.; Shabaan, M.T.; Synthesis and Antimicrobial Evaluation of Some Chalcones and Their Derived Pyrazoles, Pyrazolines, Isoxazolines, and 5,6-Dihydropyrimidine-2- $(1 \mathrm{H})$-thiones, Monatsh Chem., 2007, 138, 889. 